\title{
Paenibacillus Piscarius Sp. Nov., a Novel Nitrogen- Fixing Species Isolated from the Gut of the Armored Catfish Parotocinclus Maculicauda
}

Mariana Barbalho Farias da silva

Universidade Federal do Rio de Janeiro

Ericka Arregue Lemos

Universidade Federal do Rio de Janeiro

Renata E. Vollú

Universidade Federal do Rio de Janeiro

Fernanda Abreu

Universidade Federal do Rio de Janeiro

Alexandre S. Rosado

King Abdullah University of Science and Technology

LUCY SELDIN ( $\square$ Iseldin@micro.ufri.br)

Universidade Federal do Rio de Janeiro https://orcid.org/0000-0002-4992-6395

\section{Research Article}

Keywords: Paenibacillus piscarius, spore-forming bacteria, new species, catfish

Posted Date: September 16th, 2021

DOl: https://doi.org/10.21203/rs.3.rs-812981/v1

License: (9) (i) This work is licensed under a Creative Commons Attribution 4.0 International License.

Read Full License

Version of Record: A version of this preprint was published at Antonie van Leeuwenhoek on January 7th, 2022. See the published version at https://doi.org/10.1007/s10482-021-01694-5. 


\section{Abstract}

A gram-positive, nitrogen-fixing and endospore-forming strain, designated $\mathrm{P} 121^{\top}$, was isolated from the gut of the armored catfish (Parotocinclus maculicauda) and identified as a member of the genus Paenibacillus based on the sequences of the 16S rRNA encoding gene, $r p o B$, gyrB and nifH genes and phenotypic analyses. The most closely related species to strain $\mathrm{P} 121^{\top}$ were Paenibacillus rhizoplanae DSM $103993^{\top}$, Paenibacillus silagei DSM $101953^{\top}$ and Paenibacillus borealis DSM $13188^{\top}$, with similarity values of $98.9 \%, 98.3 \%$ and $97.6 \%$, respectively, based on 16 S rRNA gene sequences. Genome sequencing revealed a genome size of 7,513,698 bp, DNA G + C content of $53.9 \mathrm{~mol} \%$ and the presence of the structural nitrogenase encoding genes ( $n i f K$, nifD and nifH) necessary for nitrogen fixation. Digital DNA-DNA hybridization (dDDH) experiments and average nucleotide identity (ANI) analyses between strain $\mathrm{P} 121^{\top}$ and the type strains of the closest species demonstrated that the highest values were below the thresholds of $70 \% \mathrm{dDDH}$ ( $42.3 \%$ with P. borealis) and $95 \% \mathrm{ANI}(84.28 \%$ with P. silagei) for bacterial species delineation, indicating that strain $\mathrm{P} 121^{\top}$ represents a distinct species. Its major cellular fatty acid was anteiso- $\mathrm{C}_{15: 0}(42.4 \%)$, and the major isoprenoid quinone was MK-7. Based on physiological, genomic, biochemical and chemotaxonomic characteristics, we propose that strain $\mathrm{P} 121^{\top}$ represents a novel species for which the name Paenibacillus piscarius sp. nov. is proposed (type strain = DSM $25072=$ LFBFiocruz 1636).

\section{Introduction}

The genus Paenibacillus was defined in 1993 after an extensive comparative analysis of 16S RNA gene sequences of 51 species of the genus Bacillus (Ash et al. 1991; 1993). At that time, the genus comprised 11 species, with P. polymyxa as the type species. Currently, the genus comprises 263 validated species and five subspecies (http://Ipsn.dsmz.de) and harbors strains of industrial and agricultural importance relevant to humans, animals, plants, and the environment (Seldin 2011; Grady et al. 2016). Members of Paenibacillus can be found from polar regions to the tropics and from aquatic environments to the driest deserts (for review, see Grady et al. 2016). Within the genus Paenibacillus, different strains are considered plant growth-promoting bacteria (PGPB, Jeong et al. 2019) and/or are under evaluation for their use in biological control (Ruiu 2020). More than 20 Paenibacillus species encompass nitrogen-fixing strains found in different kinds of soils and in a variety of plant phyllospheres, roots and/or rhizospheres, such as wheat (Ripa et al. 2019), maize (Seldin et al. 1998; von der Weid et al. 2002), sugarcane (Seldin et al. 1984), cucumber (Hao and Chen 2017), Sabina squamata (Ma et al. 2007a), Zanthoxylum simulans (Ma et al. 2007b), Sonchus oleraceus (Hong et al. 2009), Arabidopsis thaliana (Qi et al. 2021), and many other plants.

Conversely, in a previous bioprospection study of our group carried out to search for new sources of compounds that may have economic potential (Castro et al. 2011), a novel nitrogen-fixing Paenibacillus strain - designated P121 - was isolated from the gut of the armored catfish Parotocinclus maculicauda. Fish belonging to this species are popularly known as Red Fin Dwarf Pleco and are usually found in 
southern Brazil (Garavello, 1977). The search for novel microorganisms from poorly studied environments, such as those associated with $P$. maculicauda, can bring new insights into novel genes and enzymes. The cellulolytic Paenibacillus strain previously described in Castro et al. (2011) and the novel nitrogen-fixing bacterial strain described here are good examples of this kind of study. The presence of these Paenibacillus strains in the fish gut could be explained by the diet of $P$. maculicauda, which consists mainly of plant material (Hansen and Olafsen 1999).

In this study, we report a polyphasic taxonomic description of this nitrogen-fixing bacterium strain isolated from the gut of $P$. maculicauda. The phenotypic, chemotaxonomic and genotypic properties indicate that strain $\mathrm{P} 121^{\top}$ represents a novel species within the genus Paenibacillus, for which the name Paenibacillus piscarius sp. nov. is proposed.

\section{Materials And Methods}

\section{Isolation of the bacterial strain and culture conditions}

The bacterial strain studied here was isolated from the gut of the armored catfish Parotocinclus maculicauda. Twenty fishes belonging to this species were obtained from the Mato Grosso River (Saquarema, Rio de Janeiro, Brazil) and taken to the laboratory for dissection. The food content from the digestive tract of the different fish samples was transferred to sterilized tubes, and portions of $200 \mathrm{mg}$ were mixed with $1.8 \mathrm{ml}$ of saline ( $\mathrm{NaCl} 0.85 \%$ ) and plated onto trypticase soy broth (TSB, Difco)-agar $(1.2 \%)$. After $48 \mathrm{~h}$ of incubation at $32^{\circ} \mathrm{C}$, different colonies were selected based on their morphotypes. Phylogenetic characterization of the isolates based on 16S rRNA gene sequencing surprisingly revealed that one strain (denoted $\mathrm{P} 121^{\top}$ ) clustered within the nitrogen-fixing Paenibacillus group. Therefore, it was selected for further phenotypic, phylogenetic and chemotaxonomic characterization.

\section{Bacterial DNA extraction}

DNA from strain $\mathrm{P} 121^{\top}$ was isolated according to the method described in Seldin et al. (1998). Further purification steps were those described in Seldin and Dubnau (1985). The DNA was quantified spectrophotometrically using a Qubit ${ }^{\text {TM }}$ fluorimeter (Thermo Fisher Scientific, MA, USA).

\section{Sequencing of the $16 \mathrm{~S}$ rRNA-encoding gene from strain $\mathrm{P} 121^{\top}$ and phylogenetic analysis}

The gene encoding $16 \mathrm{~S}$ rRNA from $\mathrm{P} 121^{\top}$ was amplified by PCR using the pair of universal primers pA and $\mathrm{pH}$ and the conditions described in Massol-Deya et al. (1995) and the products sequenced using Macrogen (South Korea) facilities. The 16S rRNA sequence obtained (1,447 bp) was compared with the sequences previously deposited in the GenBank database using the BLAST-N facility 
(www.ncbi.nlm.nih.gov/blast). For phylogenetic tree analysis, the sequences of closely related bacterial strains were recovered from the GenBank database and aligned to the sequence obtained in this study using the online multiple alignment program MAFFT version 7 (https://mafft.cbrc.jp/alignment/software/). Phylogenetic analyses were performed using the RaxMLHPC2 model in the CIPRES Science Gateway (Miller et al. 2010), with phylogenetic tree inference using a maximum likelihood/rapid bootstrapping run. The sequence generated in this study was deposited in NCBI GenBank under accession number JF892726.1.

\section{Whole genome sequencing (WGS) and genome features}

The whole genome of strain $\mathrm{P} 121^{\top}$ was sequenced on the Illumina Hi-seq 2500 platform as recommended by the manufacturer. An amount of approximately $5 \mu \mathrm{g} / \mu \mathrm{l}$ gDNA was used for the construction of paired-end sequencing libraries $(2 \times 150 \mathrm{bp})$ of $450 \mathrm{bp}$ insert size. Quality analysis of the final libraries was performed using a 2100 bioanalyzer (Agilent Technologies, CA, USA). The quality of the reads in the genome assembly process was checked through FastQC (Andrews 2010) and Adapter Removal (Lindgreen 2012) software. The estimated best k-mers were selected by KmerStream (Melsted and Halldórsson 2014), followed by assembly using Edena (Hernandez et al. 2008) and SPAdes (Bankevich et al. 2012). The PSI-CD-HIT package (Fu et al. 2012) was used to obtain the final contig file.

Annotation of the genome was performed by rapid annotation using Subsystem Technology server v. 2.0 (RAST; https://rast.nmpdr.org) (Aziz et al. 2008) and Prokka v.1.11 (Seemann 2014). The anti-SMASH server was used to identify the secondary metabolite biosynthesis gene clusters (Blin et al. 2019). Comparative genome analysis for Paenibacillus piscarius $\mathrm{P} 121^{\top}$, Paenibacillus borealis DSM $13188^{\top}$, Paenibacillus silagei DSM $101953^{\top}$ and Paenibacillus rhizoplanae DSM $103963^{\top}$ was performed by the OrthoVenn2 webserver (https://orthovenn2.bioinfotoolkits.net/) (Xu et al. 2019). The comparative genome map was represented through a BLASTN-based ring generated by BLAST Ring Image Generator (BRIG) version 0.95 (Alikhan et al. 2011). The P. piscarius $\mathrm{P} 121^{\top}$ genome was used as a reference for comparison.

\section{Phylogenetic analyses using 16S rRNA, rpoB, gyrB and nifH genes}

Multilocus sequence analysis (MLSA) was performed using the concatenated sequences of the $16 \mathrm{~S}$ rRNA, rpoB, gyrB and nifH genes. Partial sequences of these genes ( $g y r B-1,911 \mathrm{bp}, r p o B-3,540 \mathrm{bp}$ and nifH - $245 \mathrm{bp}$ ) from different Paenibacillus species were obtained using their genome sequences deposited in the NCBI (https://www.ncbi.nlm.nih.gov/) and JGI (https://img.jgi.doe.gov/cgi$\mathrm{bin} / \mathrm{m} / \mathrm{main}$.cgi) databases and from the draft genome sequences of strain $\mathrm{P} 121^{\top}$ determined in this study. Sequences were compared using the BLAST program. All multiple alignments were performed using the online Multiple alignment program MAFFT version 7 
(https://mafft.cbrc.jp/alignment/software/). Phylogenetic analyses were performed using the RaxMLHPC2 model in the CIPRES Science Gateway (Miller et al. 2010), with phylogenetic tree inference using a maximum-likelihood/rapid bootstrapping run. Phylogenetic trees based on the concatenated sequences were reconstructed by also applying the neighbor-joining (Saitou and Nei 1987) and maximum-parsimony (Fitch 1971) algorithms using Molecular Evolutionary Genetics Analysis (MEGA) software version X (Kumar et al. 2018). Bootstrap analysis (1,000 replications) was used to warrant cluster stability.

\section{Digital DNA-DNA hybridization (dDDH) and average nucleotide identity (ANI)}

The ANI between strain $\mathrm{P} 121^{\top}$ and the most closely related Paenibacillus species chosen in the phylogenetic trees was calculated using JSpeciesWS software (http://jspecies.ribohost.com/jspeciesws) (Ritcher et al. 2016). DNA digital hybridization (dDDH) was performed using the Genome-to-Genome Distance Calculator - GGDC 2.1 (Meier-Kolthoff et al. 2013) provided by Leibniz on the DSMZ Institute website (http://ggdc.dsmz.de/distcalc2.php) with the recommended parameters and/or default settings.

\section{Phenotypic and biochemical characterization}

Most cultural and biochemical tests were performed by using the methodology described in Gordon et al. (1973). Either TSB or TBN (Seldin et al. 1984) liquid media were used to propagate cultures ( $\mathrm{P} 121^{\top}$ and other Paenibacillus strains used in different tests for comparative purposes) for 24-48 $\mathrm{h}$ without shaking at $32^{\circ} \mathrm{C}$. Different media were supplemented with $1.2 \%$ agar to obtain solid media. Cells were observed by Nomarski differential interference contrast on a Zeiss Axioplan microscope (Carl Zeiss, Oberkochen, Germany) to determine the size of vegetative cells. The length and width $(n=700)$ of $P 121^{\top}$ cells were measured using iTEM software (iTEM Software Inc., Whiteley, UK). Gram staining was carried out by using the standard Gram reaction. Cellular motility was observed in fresh wet mounts of young (24-h) bacterial cultures in TSB. Cells were displaced on formvar-coated copper grids (Electron Microscopy Sciences, PA, USA), negatively stained with uranyl acetate $2 \%$, and observed on an FEI Morgagni transmission electron microscope (FEI Company, Hillsboro, OR, USA) operating at $80 \mathrm{kV}$ for flagella observation. For ultrathin section analysis, cells were fixed in glutaraldehyde $2.5 \%$ in sodium cacodylate buffer $0.1 \mathrm{M}$, then washed three times in the same buffer, postfixed in osmium tetroxide $1 \%$, dehydrated in acetone series and embedded in Polybed 812. Ultrathin sectioning was performed on an EM UC6 microtome (Leica Microsystems). Samples were recovered on 300-mesh copper grids (Electron Microscopy Sciences), stained with uranyl acetate and lead citrate, and observed on an FEI Morgagni transmission electron microscope (FEl Company, Hillsboro, OR, USA) at $80 \mathrm{kV}$.

For all tests that required complex media (temperature, $\mathrm{pH}$ and salinity range of growth, resistance to lysozyme, hydrolysis of starch, and liquefaction of gelatin), appropriately adjusted TSB was employed. Cell growth was monitored by the increase in optical density at $600 \mathrm{~nm}$. Anaerobic growth was observed 
by incubating a TSB-agar-containing plate inoculated with strain $\mathrm{P} 121^{\top}$ in an anaerobic chamber (filled with $80 \% \mathrm{~N}_{2}, 10 \% \mathrm{CO}_{2}$ and $10 \% \mathrm{H}_{2}$ ) for 5 days. Cytochrome oxidase was determined by the standard paper strip Kovacs oxidase test. Catalase activity was observed by bubble formation with the addition of $3 \% \mathrm{H}_{2} \mathrm{O}_{2}$ solution. The Voges-Proskauer test, formation of crystalline dextrins, utilization of citrate, reduction of nitrate to nitrite, production of indole, decomposition of casein were performed in media and conditions described in Gordon et al. (1973). Strain $\mathrm{P} 121^{\top}$ was also characterized by using the API 50CH kit (BioMérieux, France) as described in Seldin and Penido (1986). Data from API tests composed of 49 different carbohydrates were recorded as described previously (Rosado et al. 1998). An API 20NE (BioMérieux) containing 20 miniature biochemical tests was inoculated, and the biochemical results were converted into a numerical profile or code used to identify the bacteria as indicated by the manufacturer.

\section{Respiratory quinones and fatty acids}

The Identification Service and Dr. Brian Tindall, DSMZ, Braunschweig, Germany, carried out the analyses of respiratory quinones and fatty acids.

\section{Acetylene reduction}

To confirm the nitrogen-fixing capacity of strain $\mathrm{P} 121^{\top}$, acetylene reduction to ethylene (nitrogenase activity) was tested by gas chromatography as described previously (Seldin et al. 1983; 1984), using $P$. riograndensis $\mathrm{SBR}^{\top}$ and $P$. graminis $\mathrm{RSA} 19^{\top}$ as positive controls.

\section{Results And Discussion}

\section{Phylogenetic analysis of 16S rRNA gene}

Different isolates from the gut of the armored catfish Parotocinclus maculicauda were phylogenetically characterized based on $16 \mathrm{~S}$ rRNA gene sequence analysis. One strain (denoted $\mathrm{P} 121^{\top}$ ) was identified as belonging to the genus Paenibacillus, and its closest relatives were $P$. borealis DSM $13188^{\top}$, $P$. silagei DSM $101953^{\top}$ and $P$. rhizoplanae DSM $103993^{\top}$, all considered nitrogen-fixing Paenibacillus species (https://Ipsn.dsmz.de/genus/paenibacillus; Elo et al. 2001; Tohno et al. 2016; Kämpfer et al. 2017). The phylogenetic similarity indicated by the 16S rRNA gene sequence data was in agreement with the levels of $16 \mathrm{~S}$ rRNA gene sequence similarity obtained with the novel strain and $P$. rhizoplanae DSM $103993^{\top}$ (98.9\% similarity), P. silagei DSM $101953^{\top}$ (98.3\% similarity) and P. borealis DSM $13188^{\top}(97.6 \%$ similarity).

16S rRNA gene-based phylogenetic reconstruction using the maximum-likelihood algorithm, including the sequences of the most related species obtained from the GenBank database, showed that $\mathrm{P} 121^{\top}$ 
clustered and in a separate clade together with $P$. borealis DSM $13188^{\top}, P$. rhizoplanae DSM $103993^{\top}$, and P. silagei DSM $101953^{\top}$ but in an independent branch (Fig. 1).

\section{Genome sequence analysis}

The draft genome sequence of strain $\mathrm{P} 121^{\top}$ was determined in this study, and the Whole Genome Shotgun project has been deposited at DDBJ/ENA/GenBank under accession number JAIEUI000000000. The version described in this paper is version JAIEUI010000000. Genome sequencing of strain P121 resulted in a chromosome consisting of 7,513,698 bp. The G + C content was $53.9 \mathrm{~mol} \%$. According to the annotation, 6,955 coding sequences, 82 RNAs and 444 contigs were found in the $\mathrm{P} 121^{\top}$ genome. The RAST analysis revealed 317 subsystems (Fig. S1). In subsystem categories, carbohydrates had the highest feature counts (299), followed by amino acids and derivatives with 279 feature counts. As a nitrogen-fixing bacterium, genome analysis of $\mathrm{P} 121^{\top}$ revealed the presence of the nifK and nifD genes encoding dinitrogenase $\alpha$ and $\beta$ subunits (Fe-Mo protein) and the nifH gene encoding the nitrogenase iron protein. Moreover, the nifB gene involved in the biosynthesis of the iron-molybdenum cofactor (FeMo-co or M-cluster) found in the dinitrogenase enzyme was found in the $\mathrm{P} 121^{\top}$ genome.

AntiSMASH analysis resulted in the identification of eight predicted secondary metabolite biosynthetic gene clusters (BGCs). One of the BGCs matched paeninodine, a bacteriocin from the lassopeptide class, with $100 \%$ similarity. Lassopeptides are a class of ribosomally synthesized and posttranslationally modified natural products with diverse bioactivities (Maksimov et al. 2012). Another BGC showed 25\% similarity to clusters encoding the polyketide aurantinin $b / c / d$. Polyketides are a large family of structurally diverse natural products with varied biological and pharmacological activities, including antibacterial, antitumor, and immunosuppressant activities (Nivina et al. 2019). These secondary metabolites have already been described in different Paenibacillus species, such as P. polymyxa KF-1 (Li et al. 2016), P. dendritiformis C454 (Zhu et al. 2016) and P. alvei MP1 (Pajor et al. 2020).

The average nucleotide identity $(\mathrm{ANI})$ and digital DNA-DNA hybridization $(\mathrm{dDDH})$ values were determined between strain $\mathrm{P} 121^{\top}$ and the other three genomes of the closest related members of the genus Paenibacillus ( $P$. borealis DSM $13188^{\top}$, P. rhizoplanae DSM $103993^{\top}$ and $P$. silagei DSM $101953^{\top}$ ) and are shown in Table 1. The ANIb values between strain $\mathrm{P} 121^{\top}$ and $P$. borealis DSM $13188^{\top}, P$. rhizoplanae DSM $103993^{\top}$ and $P$. silagei DSM $101953^{\top}$ were $80.47 \%, 83.52 \%$ and $84.28 \%$, respectively. The accepted threshold for species delimitation using ANIb is 95-96\% (Richter and Rosselló-Móra 2009). The in silico DDH results were in all cases lower than $45 \%$, a value lower than $70 \%$, which is the cutoff value for species delineation (Goris et al. 2007). Both ANI and DDH results indicate that strain $\mathrm{P} 121^{\top}$ is a new species of the genus Paenibacillus. 
Table 1

$\mathrm{dDDH}$ and ANI values between the genome of Paenibacillus piscarius $\mathrm{P} 121^{\top}$ as the query genome and that of closely related species. ANI values were calculated using JSpecies with the ANIb algorithm

(average nucleotide identity based on BLAST). Numbers between parentheses after ANI values are percentages of conserved aligned DNA between two genomes; numbers between parentheses after dDDH values are the confidence intervals.

\begin{tabular}{|c|c|c|c|c|c|c|}
\hline $\begin{array}{l}\text { Query } \\
\text { genome }\end{array}$ & Reference genome & $\begin{array}{l}\text { Bioproject NCBI } \\
\text { number }\end{array}$ & $\begin{array}{l}\text { Size } \\
(\mathrm{Mb})\end{array}$ & $\begin{array}{l}\mathrm{G}+\mathrm{C} \\
(\mathrm{mol} \%)\end{array}$ & $\begin{array}{l}\text { dDDH } \\
(\%)\end{array}$ & $\begin{array}{l}\text { ANI } \\
(\%)\end{array}$ \\
\hline $\begin{array}{l}\text { P. piscarius } \\
\mathrm{P} 121^{\top}\end{array}$ & P. piscarius $\mathrm{P} 121^{\top}$ & JAIEUI010000000 & 7.51 & 53.9 & 100 & 100 \\
\hline $\begin{array}{l}\text { P. piscarius } \\
\mathrm{P} 121^{\top}\end{array}$ & $\begin{array}{l}\text { P. silagei DSM } \\
101953\end{array}$ & JAGGLV010000001 & 7.68 & 52.5 & $\begin{array}{l}36.1 \\
(33.7- \\
38.6)\end{array}$ & $\begin{array}{l}84.28 \\
(72.69)\end{array}$ \\
\hline $\begin{array}{l}\text { P. piscarius } \\
\mathrm{P} 121^{\top}\end{array}$ & $\begin{array}{l}\text { P. rhizoplanae } \\
\text { DSM } 103963\end{array}$ & JAGGLX010000035.1 & 7.54 & 52.1 & $\begin{array}{l}35.2 \\
(32.8- \\
37.7)\end{array}$ & $\begin{array}{l}83.52 \\
(70.12)\end{array}$ \\
\hline $\begin{array}{l}\text { P. piscarius } \\
\mathrm{P} 121^{\top}\end{array}$ & $\begin{array}{l}\text { P. borealis DSM } \\
13188\end{array}$ & PRJNA258353 & 8.16 & 51.39 & $\begin{array}{l}42.3 \\
(39.8- \\
44.8)\end{array}$ & $\begin{array}{l}80.47 \\
(60.36)\end{array}$ \\
\hline
\end{tabular}

Finally, the comparative genome analysis for $P$. piscarius $\mathrm{P} 121^{\top}, P$. borealis DSM $13188^{\top}, P$. silagei DSM $101953^{\top}$ and $P$. rhizoplanae DSM $103963^{\top}$ revealed that the strains formed 6874 clusters, 5015 orthologous clusters (at least containing two species) and 1859 single-copy gene clusters (Fig. 2). Paenibacillus piscarius $\mathrm{P} 121^{\top}$ possesses 394 singletons, proteins not found in any cluster. Figure 3 shows a circular diagram illustrating the nucleotide similarity between $P$. piscarius $\mathrm{P} 121^{\top}$ and other Paenibacillus genomes represented by concentric rings. The nif operon region in $\mathrm{P} 121^{\top}$ is highlighted and shows more than $50 \%$ similarity with $P$. borealis DSM $13188^{\top}$ nif genes.

\section{Multilocus sequence analysis (MLSA) using the housekeeping genes 16S rRNA, rpoB, gyrB and nifH}

Multilocus sequence analysis (MLSA) was performed using the concatenated sequences of the $16 \mathrm{~S}$ rRNA, rpoB, gyrB and nifH genes. Concatenation of the $16 \mathrm{~S}$ rRNA gene and the three housekeeping genes ( $r p o B, g y r B$ and $n i f H)$ of the different nitrogen-fixing Paenibacillus species and the outgroup resulted in a phylogenetic tree (Fig. S2 a) showing the same distribution as that from the 16S rRNA gene reconstruction. Again, strain $\mathrm{P} 121^{\top}$ grouped in a monophyletic group together with $P$. borealis DSM $13188^{\top}$, P. rhizoplanae DSM $103993^{\top}$ and $P$. silagei DSM $101953^{\top}$ but formed an independent branch in the tree. Similar results were also found in phylogenetic analyses performed for each gene separately (Fig. S2 b, c, d). Furthermore, the use of neighbor-joining and maximum-parsimony methods for phylogenetic reconstructions, including the sequences of the $\mathrm{P} 121^{\top}$ most related species, showed highly similar trees to those obtained using the maximum-likelihood algorithm (Fig. S3). 


\section{Phenotypic characteristics}

Strain $\mathrm{P} 121^{\top}$ was Gram-positive or Gram-variable, cells were rod-shaped measuring $0.63 \pm 0.11 \mu \mathrm{m}$ by $3.34 \pm 0.45 \mu \mathrm{m}$, motile with flagella (Fig. 4A). The spores were ellipsoidal, distending the sporangia and located in the central to subterminal position in the cell (Fig. 4B). The colonies were yellowish, circular, convex and mucoid, 10 to $15 \mathrm{~mm}$ in diameter on TSB agar.

Different phenotypic tests were used to characterize strain $\mathrm{P} 121^{\top}$ based on the recommendations of Gordon et al. (1973) and Logan et al. (2009) and are described below in the species description. Strain $\mathrm{P} 121^{\top}$ was also characterized by using API tests (API 50CH and API 20NE). It produced acid in API 50CH from L-arabinose, D-xylose, $\beta$-methyl-xyloside, glucose, D-fructose, D-mannose, mannitol, $\mathrm{N}$-acetylglucosamine, amygdalin, arbutin, esculin, salicin, cellobiose, maltose, lactose, melibiose, sucrose, trehalose, inulin, D-raffinose, starch, glycogen, $\beta$-gentibiose and turanose. A weak reaction was observed with methyl-D-mannoside, methyl-D-glucoside and xylitol. The novel strain was not able to produce acid with 22 of the other carbohydrates tested. Using API 20NE, strain $\mathrm{P} 121^{\top}$ was able to reduce nitrate to nitrite, produce urease, $\beta$-galactosidase and arginine dehydrolase, and assimilate glucose, arabinose, mannitol and maltose. Phenotypic characteristics that differentiate the novel isolate from the three closely related species Paenibacillus borealis DSM $13188^{\top}$ (Elo et al. 2001), Paenibacillus rhizoplanae DSM $103993^{\top}$ (Kämpfer et al. 2017) and Paenibacillus silagei DSM $101953^{\top}$ (Tohno et al. 2016), also considered nitrogen-fixing Paenibacillus species, are presented in Table 2. When the phenotypic characteristics of the novel isolate were compared with those of the three closely related Paenibacillus species, it became clear that $\mathrm{P} 121^{\top}$ could not be considered to represent typical members of any one of these previously established species (Table 2).

Table 2. Characteristics that differentiate strain $\mathrm{P} 121^{\top}$ from the closest type strains of selected Paenibacillus species Species: 1, strain ${\mathrm{P} 121^{\top} ;}^{\top}$ 2, P. rhizoplanae DSM $103963^{\top}$; 3, P. silagei DSM 101953'; and 4, P. borealis DSM $13188^{\top}$. +, positive reaction; -, negative reaction; nd, not determined. 


\begin{tabular}{|c|c|c|c|c|}
\hline Characteristics & 1 & 2 & 3 & 4 \\
\hline Motility & + & - & - & + \\
\hline \multicolumn{5}{|c|}{ Growth in the presence of } \\
\hline $2 \% \mathrm{NaCl}$ & - & + & + & + \\
\hline oxidase & - & + & nd & - \\
\hline Growth in pH 5.7 & - & - & nd & + \\
\hline Growth at $5^{\circ} \mathrm{C}$ & - & - & + & + \\
\hline Nitrate reduction & + & nd & nd & - \\
\hline \multicolumn{5}{|c|}{ Acid production from: } \\
\hline glycerol & - & nd & + & + \\
\hline L-arabinose & + & - & + & + \\
\hline D-xylose & + & - & + & + \\
\hline D-mannose & + & - & + & + \\
\hline Rhamnose & - & - & + & - \\
\hline Mannitol & + & - & + & - \\
\hline Maltose & + & - & + & nd \\
\hline Lactose & + & - & + & + \\
\hline Melezitose & - & nd & - & + \\
\hline D-arabitol & - & - & - & + \\
\hline
\end{tabular}

\section{Chemotaxonomic characteristic}

In accordance with other species of the genus Paenibacillus, meso-diaminopimelic acid was detected. The quinone system was composed predominantly of menaquinones MK-7, which is also in line with other species of the genus.

The fatty acids comprised mainly iso- and anteiso-branched components, and the fatty acid profile was very similar to those of the most closely related Paenibacillus species. The major cellular fatty acids are anteiso- $\mathrm{C}_{15: 0}$, iso- $\mathrm{C}_{16: 0}$, iso- $\mathrm{C}_{15: 0}$ and $\mathrm{C}_{14: 0}$. The detailed cellular fatty acid profiles (\%) of P. piscarius $\mathrm{sp}$. nov. $\mathrm{P} 121^{\top}$ and closely related Paenibacillus species is shown in Table S1. 


\section{Nitrogen fixation}

The new isolate, together with the $P$. graminis and $P$. riograndensis type strains (RSA $19^{\top}$ and $S B R 5^{\top}$, respectively), effectively reduced acetylene, showing values varying from 2.08 to $4.73 \mathrm{nmol}$ ethylene/mg protein/h (Table 3).

Table 3. Nitrogenase activity of strain $\mathrm{P} 121^{\top}$ compared with two other nitrogen-fixing Paenibacillus species

The results are the means \pm standard deviation of triplicates; $\left.{ }^{*}\right)$ two independent experiments.

\begin{tabular}{|ll|}
\hline Strain & $\begin{array}{l}\text { Acetylene reduction } \\
\text { (nmol ethylene per } \mathrm{mg} \text { protein per } \mathrm{h} \text { ) }\end{array}$ \\
\hline${\mathrm{P} 121^{\top}}^{\top}$ & $2.43 \pm 0.28 / 3.36 \pm 0.23^{*}$ \\
P. riograndensis SBR5 $^{\top}$ & $4.73 \pm 0.63$ \\
\hline P. graminis RSA19 & \\
\hline
\end{tabular}

\section{Description of Paenibacillus piscarius sp. nov.}

Paenibacillus piscarius (pis.ca'ri.us. L. masc. adj. piscarius, of or pertaining to fish).

Cells are straight, motile rods $(0.63 \pm 0.11 \mu \mathrm{m}$ in width, $3.34 \pm 0.45 \mu \mathrm{m}$ in length) with flagella. Spores are oval to ellipsoidal and predominantly central to subterminal and distend the sporangium. Young trypticase soy broth (TSB) cultures are Gram-positive or Gram-variable. On TSB agar, colonies are 10 to $15 \mathrm{~mm}$ in diameter, yellowish, circular, convex and mucoid. Do not grow at $10^{\circ} \mathrm{C}$ or $40^{\circ} \mathrm{C}$; optimum is near $25^{\circ} \mathrm{C}$. Growth was not observed at $\mathrm{pH} 5.7$ (optimum $\mathrm{pH} 7.5-8$ ) or in the presence of $2 \% \mathrm{NaCl}$. Resistant to $0.001 \%$ lysozyme. Facultatively anaerobic. Catalase and urease are produced. Voges-Proskauer negative. Nitrate is reduced to nitrite. Gelatin is not liquefied. Starch hydrolysis was negative, and esculin hydrolysis was positive. No crystalline dextrins are formed in rolled oat medium. Casein is weakly decomposed. Indole is not produced. Acid is produced from L-arabinose, D-xylose, $\beta$ methyl-xyloside, glucose, Dfructose, D-mannose, mannitol, $\mathrm{N}$ acetyl glucosamine, amygdalin, arbutin, esculin, salicin, cellobiose, maltose, lactose, melibiose, sucrose, threalose, inulin, D-raffinose, starch, glycogen, gentibiose and turanose. Strain $\mathrm{P} 121^{\top}$ does not produce acid from glycerol, erythritol, D-arabinose, ribose, L-xylose, adonitol, galactose, L-sorbose, rhamnose, dulcitol, inositol, sorbitol, melezitose, D-lyxose, D-tagatose, Dfucose, L-fucose, D-arabitol, L-arabitol, gluconate, 2 keto-gluconate or 5 keto-gluconate. A weak reaction was observed with xylitol, a-methyl-D-glucoside, and a-methyl-D-mannoside. Assimilation of maltose and 
mannitol was positive but negative for mannose and N-acetyl-glucosamine. Utilization of gluconate, caprate, adipate, malate, citrate and phenyl-acetate was not observed. Nitrogen fixation (acetylene reduction) was detected. The $\mathrm{G} \neg \mathrm{C}$ content of the type strain is $53.9 \mathrm{~mol} \%$. The major cellular fatty acids are anteiso- $\mathrm{C}_{15: 0}$, iso- $\mathrm{C}_{16: 0}$, iso- $\mathrm{C}_{15: 0}$ and $\mathrm{C}_{14: 0}$. Isolated from the gut of the armored catfish Parotocinclus maculicauda. The type strain is LFB-Fiocruz 1636, DSM $25072\left(=\mathrm{P} 121^{\top}\right)$.

\section{Declarations}

\section{Acknowledgments}

This study was supported by grants from Conselho Nacional de Desenvolvimento Científico e Tecnológico (CNPq), Coordenação de Aperfeiçoamento de Pessoal de Nível Superior (CAPES, financial code 001) and Fundação de Amparo à Pesquisa do Estado do Rio de Janeiro (FAPERJ).

\section{Author's contributions}

LS and ASR conceived the study. REV performed deposition, and LS and REV performed the polyphasic taxonomy. MBFS and EAL performed genome analysis. FA provided transmission electron microscope data. LS drafted the manuscript. All authors revised the manuscript, provided comments and approved the final version of the manuscript.

\section{Declarations Conflict of interest}

The authors declare that they have no conflicts of interest.

\section{Ethical approval}

This article does not contain any studies with human participants. The isolation of the Paenibacillus strain from the gut of the armored catfish described here followed the recommendations of the Guide for the Care and Use of Laboratory Animals of the Laboratory of Biology and Fisheries Technology, Institute of Biology, UFRJ.

\section{References}

1. Alikhan NF, Petty NK, Zakour NLB, Beatson SA (2011) BLAST Ring Image Generator (BRIG): simple prokaryote genome comparisons, BMC Genom 12:402

2. Andrews S (2010) FastQC: A Quality Control Tool for High Throughput Sequence Data [Online]. Available online at: http://www.bioinformatics.babraham.ac.uk/projects/fastqc/

3. Ash C, Farrow JAE, Wallbanks S, Collins M D (1991) Phylogenetic heterogeneity of the genus Bacillus revealed by comparative analysis of small subunit-ribosomal RNA sequences. Lett Appl Microbiol 13:202-206 
4. Ash C, Priest FG, Collins MD (1993) Molecular identification of rRNA group 3 bacilli (Ash, Farrow, Wallbanks and Collins) using a PCR probe test. Proposal for the creation of a new genus Paenibacillus. Antonie van Leeuwenhoek 64:253-260

5. Aziz RK, Bartels D, Best,AA, DeJongh M, Disz T, et al. (2008) The RAST Server: Rapid Annotations using Subsystems Technology. BMC Genom 9:75

6. Bankevich A, Nurk S, Antipov D, Gurevich AA, Dvorkin M et al. (2012) SPAdes: a new genome assembly algorithm and its applications to single-cell sequencing. J Comput Biol 19:455-477

7. Blin K, Shaw S, Steinke K, Villebro R, Ziemert N, Lee SY, Medema MH, Weber T (2019) antiSMASH 5.0: updates to the secondary metabolite genome mining pipeline. Nucl Acids Res 47:81-87

8. Castro ALM, Vollú RE, Peixoto RS, Grigorevski-Lima AL, Coelho RRR, Bon EPS, Rosado AS, Seldin L (2011) Cellulolytic potential of a novel strain of Paenibacillus sp. isolated from the armored catfish Parotocinclus maculicauda gut. Braz J Microbiol 42(4):1608-1615

9. Elo S, Suominen I, Kämpfer P, Juhanoja J, Salkinoja-Salonen M, Haahtela K (2001) Paenibacillus borealis sp. nov., a nitrogen-fixing species isolated from spruce forest humus in Finland. Int J Syst Evol Microbiol 51:535-545

10. Fitch WM (1971) Toward defining the course of evolution: minimum change for a specific tree topology. Syst Zool 20:406-416

11. Fu L, Niu B, Zhu Z, Wu S, Li W (2012) CD-HIT: accelerated for clustering the next-generation sequencing data. Bioinformatics 28:3150-3152

12. Garavello JC (1977) Systematics and geographical distribution of the genus Parotocinclus, Eigenmann \& Eigenmann, 1889 (Ostariophysi, Loricariidae). Arq Zool S Paulo 28:1-37

13. Gordon R E, Haynes WC, Pang H-N (1973) The genus Bacillus. Agriculture Handbook 427, Agricultural Research Service, U.S. Department of Agriculture, Washington, D.C.

14. Goris J, Konstantinidis KT, Klappenbach JA, Coenye T, Vandamme P, Tiedje JM (2007) DNA-DNA hybridization values and their relationship to whole-genome sequence similarities. Int J Syst Evol Microbiol 57:81-91

15. Grady EN, MacDonald J, Liu L, Richman A, Yuan Z-C (2016) Current knowledge and perspectives of Paenibacillus: a review. Microb Cell Fact 15(1):203

16. Hansen GH, Olafsen JA (1999) Bacterial interactions in early life stages of marine cold water fish. Microb Ecol 38:1-26

17. Hao T, Chen S (2017) Colonization of Wheat, Maize and Cucumber by Paenibacillus polymyxa WLY78. PLoS ONE 12(1):e0169980

18. Hernandez D, François P, Farinelli L, Osterås M, Schrenzel J (2008) De novo bacterial genome sequencing: millions of very short reads assembled on a desktop computer. Genome Res 18(5):802809

19. Hong YY, Ma YC, Zhou YG, Gao F, Liu HC, Chen SF (2009) Paenibacillus sonchisp. nov., a nitrogenfixing species isolated from the rhizosphere of Sonchus oleraceus. Int J Syst Evol Microbiol. 
59:2656-2661

20. Jeong H, Choi S-K, Ryu C-M, Seung-Hwan Park S-H (2019) Chronicle of a soil bacterium: Paenibacillus polymyxa E681 as a tiny guardian of plant and human health. Front Microbiol 10:467

21. Kampfer P, Busse H-J, Mclnroy JA, Hu C-H, Kloepper JW, Glaeser SP (2017) Paenibacillus rhizoplanae sp. nov. isolated from the rhizosphere of Zea mays. Int J Syst Evol Microbiol 67:1058-1063

22. Kumar S, Stecher G, Li M, Knyaz C, Tamura K. MEGA X: molecular evolutionary genetics analysis across computing platforms. Mol Biol Evol 2018;35:1547-1549.

23. Li Y, Li Q, Li Y, Gao J, Fan, X (2016) Draft genome sequence of Paenibacillus polymyxa KF-1, an excellent producer of microbicides. Genome Announc 4(4):e00727-16

24. Lindgreen (2012) AdapterRemoval: easy cleaning of next-generation sequencing reads. BMC Res Notes 5:337

25. Logan NA, Berge O, Bishop AH, Busse H-J, De Vos P, Fritze D, Heyndrickx M, Kämpfer P, Rabinovitch L, Salkinoja-Salonen MS, Seldin L, Ventosa A (2009) Proposed minimal standards for describing new taxa of aerobic, endospore-forming bacteria. Int J Syst Evol Microbiol 59: 2114-2121

26. Ma Y, Xia Z, Liu X, Chen S (2007a) Paenibacillus sabinae sp. nov., a nitrogen-fixing species isolated from the rhizosphere soils of shrubs. Int J Syst Evol Microbiol 57:6-11

27. Ma Y, Zhang J, Chen S (2007b) Paenibacillus zanthoxyli sp. nov., a novel nitrogen-fixing species isolated from the rhizosphere of Zanthoxylum simulans. Int J Syst Evol Microbiol 57:873-877

28. Maksimov MO, Pan SJ, A James Link AJ (2012) Lasso peptides: structure, function, biosynthesis, and engineering. Nat Prod Rep 29:996-1006

29. Massol-Deya AA, Odelson DA, Hichey RP, Tiedje JM (1995). Bacterial community fingerprinting of amplified 16S and 16-23S ribosomal DNA gene sequences and restriction endonuclease analysis (ARDRA). In: Akkermans ADL, van Elsas JD, de Bruijn FJ (eds) Molecular Microbial Ecology Manual, Kluwer Academic Publishers, Netherlands, pp. 3.3.2: 1-8

30. Meier-Kolthoff JP, Auch AF, Klenk HP, Goker M (2013) Genome sequence-based species delimitation with confidence intervals and improved distance functions. BMC Bioinformatics 14:60.

31. Melsted P, Halldórsson BV (2014) KmerStream: streaming algorithms for k-mer abundance estimation. Bioinformatics 30:3541-3547

32. Miller MA, Pfeiffer W, Schwartz T (2010) Creating the CIPRES Science Gateway for inference of large phylogenetic trees. In: Proceedings of the Gateway Computing Environments Workshop (GCE), New Orleans, LA, pp 1-8

33. Nivina A, Yuet KP, Hsu J, Khosla C. (2019) Evolution and diversity of assembly line polyketide synthases. Chem Rev 119:12524-12547

34. Pajor M, Sogin J, Worobo R, Szweda P (2020) Draft genome sequence of antimicrobial producing Paenibacillus alvei strain MP1 reveals putative novel antimicrobials. BMC Res Notes 13:280

35. Qi SS, Cnockaert M, Carlier A, Vandamme PA (2021) Paenibacillus foliorum sp. nov., Paenibacillus phytohabitans sp. nov., Paenibacillus plantarum sp. nov., Paenibacillus planticolens sp. nov., 
Paenibacillus phytorum sp. nov. and Paenibacillus germinis sp. nov., isolated from the Arabidopsis thaliana phyllosphere. Int J Syst Evol Microbiol 71: doi: 10.1099/ijsem.0.004781

36. Richter M, Rosselló-Móra R, Glöckner FO, Peplies J (2016) JSpeciesWS: a web server for prokaryotic species circumscription based on pairwise genome comparison. Bioinformatics 32: 29-31

37. Ripa FA, Tong S, Cao W-D, Wang ET, Wang T, Liu HC, Gao J-L, Sun J-G (2019) Paenibacillus rhizophilus sp. nov., a nitrogen-fixing bacterium isolated from the rhizosphere of wheat (Triticum aestivum L.). Int J Syst Evol Microbiol 69: 3689-3695

38. Rosado AS, de Azevedo FS, da Cruz DW, van Elsas JD, Seldin L (1998) Phenotypic and genetic diversity of Paenibacillus azotofixans strains isolated from the rhizoplane or rhizosphere soil of different grasses. J Appl Microbiol 84:216-226

39. Ruiu L (2020) Plant-Growth-Promoting Bacteria (PGPB) against insects and other agricultural pests. Agronomy 10(6):861

40. Saitou N, Nei M (1987) The neighbor-joining method: A new method for reconstructing phylogenetic trees. Mol Biol Evol 4, 406-425

41. Seemann T (2014) Prokka: rapid prokaryotic genome annotation. Bioinformatics 30(14):2068-2069

42. Seldin L (2011) Paenibacillus, nitrogen fixation and soil fertility. In: Logan NA, De Vos P (eds) Aerobic, endospore-forming soil bacteria, Springer-Verlag, Berlin-Heidelberg-New York. 315 pp.

43. Seldin L, Dubnau D (1985) DNA homology among Bacillus polymyxa, Bacillus macerans, Bacillus azotofixans and others nitrogen fixing Bacillus strains. Int Syst Bacteriol 35:151-154

44. Seldin L, Penido EGC (1986) Identification of Bacillus azotofixans using API tests. Antonie van Leeuwenhoek J Microbiol Serol 52:403-409

45. Seldin L, Rosado AS, Cruz DW, Nobrega A, van Elsas JD, Paiva E (1998) Comparison of Paenibacillus azotofixans strains isolated from rhizoplane, rhizosphere and non-rhizosphere soil from maize planted in two different Brazilian soils. Appl Environ Microbiol 64:3860-3868

46. Seldin L, van Elsas JD, Penido EGC (1983) Bacillus nitrogen fixers from Brazilian soils. Plant Soil 70:243-255

47. Seldin L, van Elsas JD, Penido EGC (1984) Bacillus azotofixans sp. nov., a nitrogen-fixing species from Brazilian soils and grass roots. Int J Syst Bacteriol 34, 451- 456

48. Tohno M, Sakamoto M, Ohkuma M, Tajima K (2016) Paenibacillus silagei sp. nov. isolated from corn silage. Int J Syst Evol Microbiol 66: 3873-3877

49. von der Weid I, Duarte GF, van Elsas JD, Seldin L (2002) Paenibacillus brasilensis sp. nov., a new nitrogen-fixing species isolated from the maize rhizosphere in Brazil. Int J Syst Evol Microbiol 52:2147-2153

50. Xu L, Dong Z, Fang L, Luo Y, Wei Z, Guo H, Zhang G, Gu YQ, Coleman-Derr D, Xia Q, Wang Y (2019) OrthoVenn2: a web server for whole-genome comparison and annotation of orthologous clusters across multiple species. Nucl Acids Res 47:W52-W58 
51. Zhu S, Hegemann J, Fage C, Zimmermann M, Xie X, Linne U, Marahiel M (2016) Insights into the unique phosphorylation of the lasso peptide paeninodin. J Biol Chem 291:26.

\section{Figures}

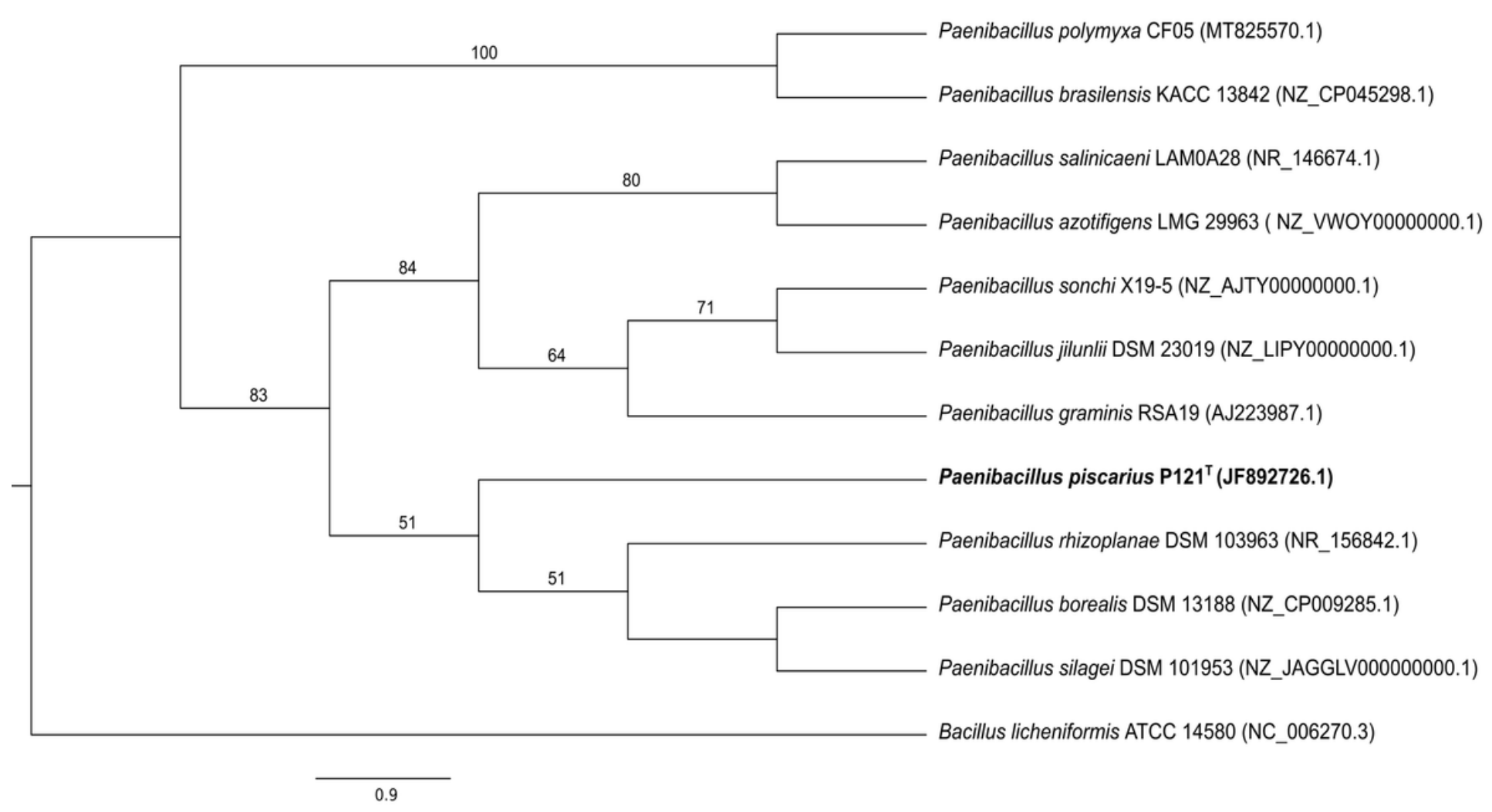

\section{Figure 1}

Maximum likelihood tree with GTRGAMMA distribution of the multiple alignment of the 16S rRNA encoding gene of Paenibacillus piscarius P121T and related species. The GenBank accession number of each sequence is shown in parentheses. Bootstrap values are expressed as percentages of 1000 replications and are shown at branch points. Bacillus licheniformis ATCC 14580 was used as outgroup. Bar = substitutions per nucleotide position. 


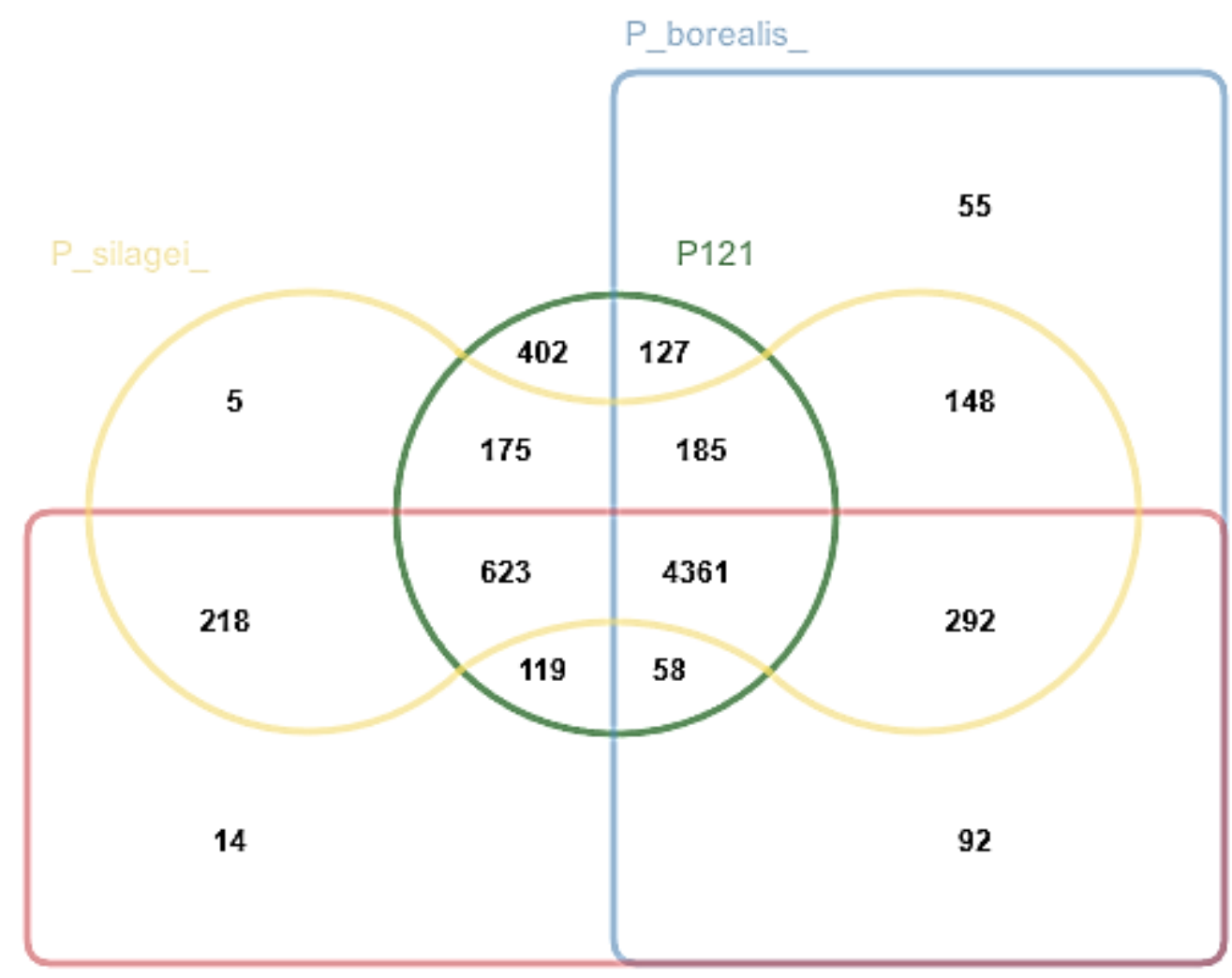

P_rhizoplanae_

\section{Figure 2}

Comparative genome analysis for Paenibacillus piscarius P121T, Paenibacillus borealis DSM 13188T, Paenibacillus silagei DSM 101953T and Paenibacillus rhizoplanae DSM 103963T performed by the OrthoVenn2 webserver. The numbers in the Venn diagram represent the number of clusters shared between strains. 


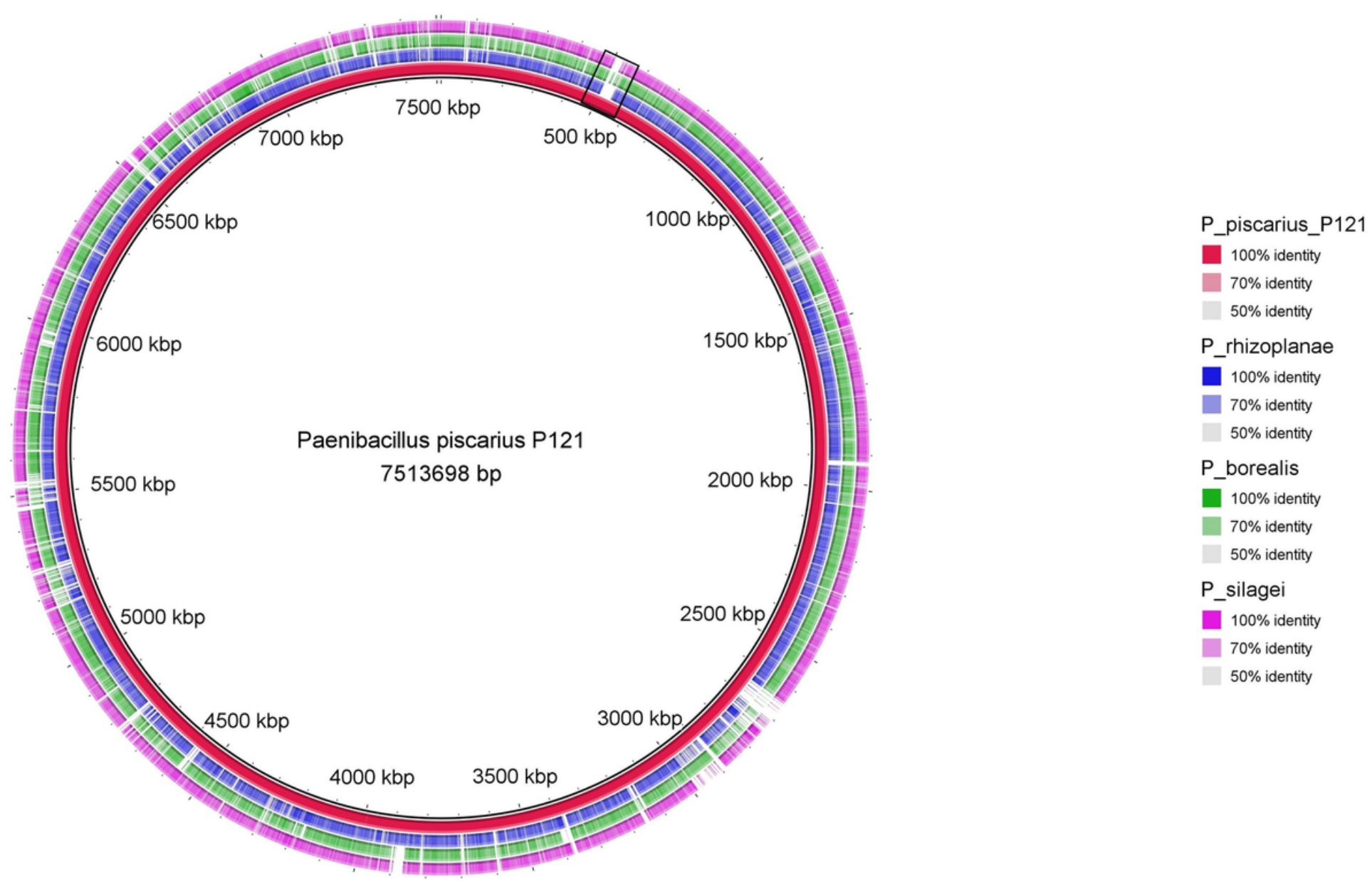

\section{Figure 3}

Circular diagram illustrating the nucleotide similarity between P. piscarius P121T (in red) and other Paenibacillus genomes represented by concentric rings. The nif genes region is delimited in black.

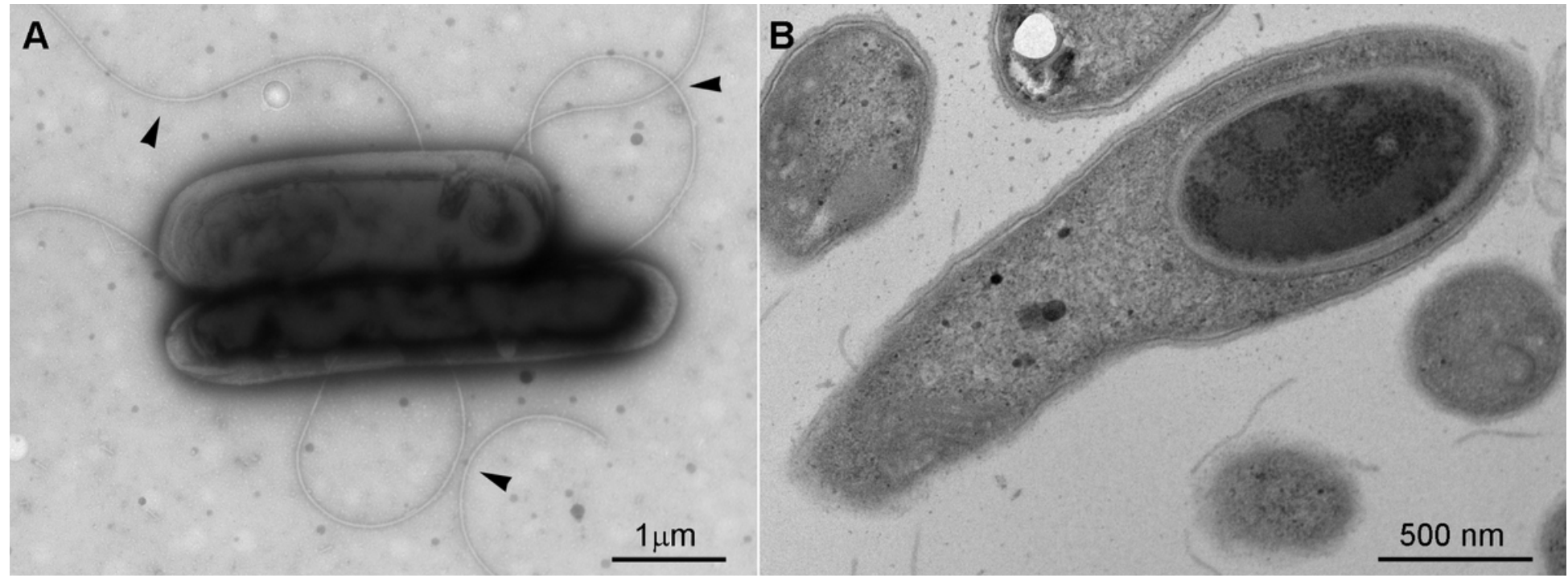

Figure 4 
Transmission electron micrographs of isolate P121T. (A) Vegetative cells with flagella; (B) ellipsoidal spore, swelling the sporangia.

\section{Supplementary Files}

This is a list of supplementary files associated with this preprint. Click to download.

- Supplementalmaterialpiscarius10sept21.doc 